\title{
The Measurement Model of Supply Chain Uncertainty and Risk in the Australian Courier Industry
}

\author{
Michael Wang \\ School of Business IT and Logistics, RMIT University, Melbourne, Australia \\ E-mail: Michael.wang@rmit.edu.au (Corresponding Author) \\ Ferry Jie \\ School of Business IT and Logistics, RMIT University, Melbourne, Australia \\ E-mail: Ferry.jie@rmit.edu.au \\ Ahmad Abareshi \\ School of Business IT and Logistics, RMIT University, Melbourne, Australia \\ E-mail: Ahmad.abareshi@rmit.edu.au
}

\begin{abstract}
Courier is a booming industry in today's world. Courier company is one of the most significant 3PLs modules. With the development of globalisation, e-business, shorter product and technology life cycles and higher customer expectations, courier service providers face more supply chain uncertainty and risk than ever before. The supply chain uncertainty and risk has significant impacts on logistics performance in the courier service providers. Uncertainties and risks are interchangeable and inseparable. Moreover, in a real world environment, managers have to face and manage both supply chain uncertainty and risk simultaneously. The purpose of this paper is to present the results for development of an empirically validated measurement of supply chain uncertainty and risk in the Australian courier industry. The empirical data was collected in the Australian courier industry. A measurement model of structural equation modelling is used to identify the underlying factors of supply chain uncertainty and risk in the Australian courier industry. They are (1) companyside uncertainty and risk, (2) customer-side uncertainty and risk, and (3) environment uncertainty and risk. The results indicate high levels of reliability and validity of the measurement. This measurement model contributes to the supply chain uncertainty and risk literature. In addition, it provides an insight into assess supply chain uncertainty and risk in an industry.
\end{abstract}

Keywords: Supply chain uncertainty and risk, risk management, risk assessment, courier, logistics.

\section{INTRODUCTION}

Supply chain uncertainty and risk have been widely recognised as an issue in today' supply chain and logistics (Miller, 1992; Davis, 1993; Prater, 2005; Lee, 2002; Rodrigues et al., 2010). Both supply chain uncertainty and risk influence decision makers in the supply chain resulting in ineffectiveness and inefficiency (Vorst and Beulens, 2002), which ultimately affect the organisational performance. In this paper, supply chain uncertainty and risk is defined as the impacts, consequences, unexpected outcome and/or problems, they were caused by incidents, disaster and/or errors may harm the logistics performance of logistics and transport service providers. In a real world environment, managers have to deal with supply chain uncertainty and risk simultaneously. It is important to consider and manage them together.

Supply chain risk management is one of the fastest growing areas in logistics research (Andreas and Carl Marcus, 2012). And supply chain uncertainty management is not a new concept, a considerable amount of research has been undertaken on uncertainty in supply chain management (Davis, 1993; Mason-Jones and Towill, 1998; Prater et al., 2001; Rodrigues et al., 2008; Simangunsong et al., 2012). It is important that smooth operations of every link in the supply chain should be taken care of. Uncertainty in the functioning of any of the links may lead to delays and bottlenecking and may hamper the performance output of the supply chain (Patil et al., 2012).

Effective risk management is driven by both theory and practice. Risk management best practices can only emerge when the theories and models are proved in a real world environment (Lam, 2003). The concepts of supply chain risk management and supply chain uncertainty management are very similar (Simangunsong et al., 2012). For example Manuj and Mentzer (2008) summarise the existing literatures from supply chain and related disciplines to suggest a five-step process for supply chain risk management. Those five steps include (1) risk identification, (2) risk assessment and evaluation, (3) selection of appropriate risk management strategies, (4) strategy implementation, and (5) mitigation of supply chain risks. Aven (2011) and Simangunsong et al. (2012) argue it is essential to identify and verify the sources of risk and uncertainty in supply chain risk and uncertainty management and assess them. Moreover, risk management has the same perspective as a coping with uncertainty strategy (Simangunsong et al., 2012).

Measuring the uncertainty and risk is one critical step in the risk management process (Aven, 2011). The most 
important aspect of risk management is the integration of risk into a company's culture and values, risk management targets should be included among corporate goals, and major corporate initiatives should incorporate risk assessment and risk mitigation strategies (Lam, 2003). This paper reports the results and findings of a study carried out to develop the measurement of supply chain uncertainty and risk in the Australian courier industry. We proposed 29-item instrument with four major supply chain uncertainty and risk constructs including logistics uncertainty and risk, information uncertainty and risk, customer-related uncertainty and risk, and environment uncertainty and risk based on the extensive literature review. Empirical data was collected in the Australian courier industry. According to factor analysis, the three underlying factors of supply chain uncertainty and risk in the Australian courier industry are found. This enables the managers to have a better understanding of supply chain uncertainty and risk in the Australian courier industry. Moreover, the measurement model can be used by both academics and practitioners as a guidance for supply chain uncertainty and risk management and further studies.

\section{THEORETICAL BACKGROUND}

\subsection{Uncertainty and Risk}

According to Oxford English Dictionary, risk is the possibility of loss, injury, or other adverse or unwelcome circumstance; a chance or situation involving such a possibility. The general definition of uncertainty is the quality of being uncertain in respect of duration, continuance, occurrence, etc.; liability to chance or accident. Another definition of uncertainty under Economics is a business risk which cannot be measured and whose outcome cannot be predicted or insured against.

In an attempt to distinguish difference between risk and uncertainty, Knight (1921) argues that uncertainty is risk that is immeasurable, and risk is defined as uncertainty based on well-grounded probability. Miller (1992) posits that risks in business refers to unanticipated variation or negative variation which may influence business performance such as revenues, costs, profit, market share, and uncertainty refers to the unpredictability of environmental or organisational variables that impact business performance or the insufficient information about these variables.

Generally speaking, risks and uncertainties occur because people do not have sufficient knowledge to understand exactly what will happen in the future. People can use the best techniques and do every possible analysis, but there is always unknown about future events. There is a very close relationship between risk and uncertainty, because uncertainty increase the possibility of risk occurrence, and risk is a consequence of uncertainty (Aven, 2011). In other words risk occurs because of uncertainty about the future, this uncertainty means that unexpected events may occur, and when these unexpected events occur, they cause some kind of damage (Waters, 2011).

There is an interesting statement about risk and uncertainty - "Risk is if we don't know what will happen next, but we do know what the distribution looks like. Uncertainty is if we don't know what will happen next, and we do not even know what the possible distribution looks like (Ritholtz, 2012)." This statement reflects a similar understanding of Knight (1921), in other words uncertainty is not able to be forecasted or expected beforehand.

\subsection{Supply Chain Uncertainty and Risk}

Risk and uncertainty is a major topic in the supply chain literature (Prater, 2005; Davis, 1993; SanchezRodrigues et al., 2008; Simangunsong et al., 2012). The definition of supply chain uncertainty was given by Vorst and Beulens (2002) as follows.

"Decision-making situations in the supply-chain in which the decision-maker does not know definitely what to decide as he / she is indistinct about the objectives; lacks information about (or understanding of) the supply-chain or its environment; lacks information processing capacities; is unable to accurately predict the impact of possible control actions on supply-chain behavior; or lacks effective control actions (non-controllability)" (Vorst and Beulens, 2002, p. 413).

March and Shapira (1987, p. 1404) define "risk as the variation in the distribution of possible supply chain outcomes, their likelihood, and their subjective values". The supply chain risks comprise "any risks for the information, material and product flows from original supplier to the delivery of the final product for the end user" (Jüttner et al., 2003, p. 200).

According to Sanchez-Rodrigues et al. (2008), "risk is a function of outcome and probability and hence it is something that can be estimated. If the probability that an event could occur is low, but the outcome of that event can have a highly detrimental impact on the supply chain, the occurrence of that event represents a considerable risk for the chain. Uncertainty occurs when decision makers cannot estimate the outcome of an event or the probability of its occurrence” (Sanchez-Rodrigues et al., 2008, p. 390).

Supply chain uncertainty and risk usually are interchangeable in practice (Peck, 2006; Jüttner et al., 2003; Ritchie and Brindley, 2007). Jüttner et al. (2003), Peck (2006) and Prater (2005) suggest that the difference between supply chain uncertainty and risk is blurred to the extent that it is not important to distinguish. Many supply chains risks are related to the uncertainty and they are inseparable (Prater, 2005; Simangunsong et al., 2012; Sanchez-Rodrigues et al., 2008; Rodrigues et al., 2010; McManus and Hastings, 2006). However, some researchers suggest that risk is only associated with issues that may lead to negative outcomes e.g. Miller (1992), Peck (2006), and Wagner and Bode (2008). Technically, although risk and uncertainty are two different concepts (Peck, 2006; Simangunsong et al., 2012; Rodrigues et al., 2010; Sanchez-Rodrigues et al., 2008; Knight, 1921), for managers, it is important to consider and assess them together in a real world environment. In this paper, supply chain uncertainty and risk is defined as the impacts, consequences, unexpected outcome and/or problems may harm the performance of different parties in a supply chain.

Supply chain uncertainty and risk are complex notions that come in many different forms and may include supply chain uncertainty and risk sources, risk consequences and risk drivers (Christopher and Lee, 2004; Manuj and Mentzer, 2008; Rodrigues et al., 2008). It is significant to categorise 
the different types of supply chain uncertainties and risks in terms of the actual industries and businesses. Different industries and businesses may have different sources and drivers of supply chain uncertainties and risks.

Hult et al. (2010) illustrate uncertainty inherent in the supply chain had an exogenous element for any given participant. For managers, risk is a threat that something might happen to disrupt normal activities or stop things happening as planned (Waters, 2011). In addition many other distinct sources of uncertainty had received insufficient attention in supply chain (Prater, 2005).

Overall, although there are some differences between uncertainty and risk in a deeper level analysis, it is not indispensable to distinguish them, because supply chain uncertainty and risk usually are interchangeable in practice (Peck, 2006; Jüttner et al., 2003; Ritchie and Brindley, 2007). More importantly, in a real-world environment, managers have to face both supply chain uncertainty and risk and manage them simultaneously. Therefore, this study does not focus on distinguishing the uncertainty and risk. Instead, the research considers the ways to measure both uncertainties and risks simultaneously without separate them in logistics and transport service providers.

\section{MEASUREMENT DEVELOPMENT IN THE AUSTRALIAN COURIER INDUSTRY}

\subsection{The Four Categories of Supply Chain Uncertainties and Risks}

Based on extensive literature review on logitsics and supply chain management, four categories of supply chain uncertainties and risks were proposed (Figure 1). These four categories include: 1) logistics uncertainty and risk, 2) information uncertainty and risk, 3) customer-related uncertainty and risk and 4) environmental uncertainty and risk (Murugesan et al., 2013; Simangunsong et al., 2012; Sanchez-Rodrigues et al., 2010)

Measure of supply chain uncertainties and risks is one of the important parts of supply chain uncertainty and risk management (Aven, 2011). Supply chain uncertainty and risk in transport is a part of contingent uncertainty and risk models (Sanchez-Rodrigues et al., 2008). It is ineffective and inefficient to investigate and measure every single source of contingent uncertainties and risks in logistics and transport service providers, due to different companies may have different uncertainties and risks. However it is possible to measure the impacts under the same category of supply chain uncertainties and risks in the separate companies, because the same category of supply chain uncertainties and risks may cause common problems in companies. It is easy for managers to monitor and assess these uncertainties and risks. Therefore, the supply chain uncertainties and risks are measured by their impacts of uncertainties and risks, which obstruct the logistics performance of logistics and transport service providers.

\section{- $\quad$ Logistics Uncertainty and Risk}

Logistics is described as a time-sensitive process of flow of goods and information from a point of origin to a destination point (Christopher, 1998), and supply chain uncertainties and risks in this paper are concentrated on logistics and transport service providers. Logistics uncertainty and risk can broadly be categorized as the potential disturbances to the flow of goods, information, and money (Ellegaard, 2008). In this paper, logistics uncertainty and risk is defined as weakness, faulty, error, loss and /or unexpected outcome may influence normal logistics-related activities / processes in transport service providers. The variables of logistics uncertainty and risks in literature include delays, transport network, storage, carrier strength and freight (Rodrigues et al., 2008; Simangunsong et al., 2012; Hauser, 2003).

\section{- Information Uncertainty and Risk}

In this paper information uncertainty and risk is defined as information-related unexpected incidents; outcome and / or problems may influence information in time, accuracy and availability in logistics and transport service providers. Information is the aider in the smooth functioning of the supply chain. The sources of information uncertainty and risk identified in literature include information delays, unavailability of information, information infrastructure, and information and communication issues. (Guo et al., 2006; Cucchiella and Gastaldi, 2006; Blackhurst et al., 2008; Sanchez-Rodrigues et al., 2010).

\section{- $\quad$ Customer-related Uncertainty and Risk}

Customer related uncertainty and risk are most likely occurred between the logistics service providers and customers. It is difficult to draw a clear boundary between different uncertainties and risks. However in this paper, the definition of customer-related uncertainty and risk is a part of supply chain uncertainty and risk, which mainly originate from customer side rather than companies, may cause disputes and / or influence the normal logistics operations in logistics service providers. Due to the nature of courier industry, receivers and senders play an equal important role in the industry. Therefore it is important to consider both receivers and senders together. In literature, there are various customer-related uncertainties and risks include: unanticipated customer, reputation, forecast error, delays to customer, receivable risks. (Manuj and Mentzer, 2008; Sodhi and Lee, 2007; Chopra and Sodhi, 2004; Sodhi and Tang, 2012).

\section{- Environment Uncertainty and Risk}

Uncertainty and risk can arise due to the interactions between the supply chain network and its external environment / events. The environment uncertainty and risk have been considered widely in previous studies (Simangunsong et al., 2012). It is significant to think about the environment uncertainty and risk, most environment uncertainty and risk are unavoidable, such as road congestions / closures and natural disaster. Therefore the logistics service providers have to consider these factors beforehand. In this study, we consider the environment uncertainty and risk form these five factors include: labor, 
road congestion, natural disasters, fuel price, and regulations.(Blackhurst et al., 2008; McKinnon and Ge, 2004; Sanchez-Rodrigues et al., 2010; Simangunsong et al., 2012).

\subsection{Scale Development}

Measuring supply chain uncertainty and risk based on the actual courier industry operations, previous studies and interviews with supply chain and logistics academics and practitioners in the Australian courier industry. Usually, three major parties - courier service providers, consignors and consignees, are involved in a courier delivery. The measurements are used for first time in the Australian courier industry. Therefore, it is important to assess the reliability and validity, and conduct appropriate factor analysis.

First of all, a pilot study is conducted for testing measurement validity including face validity, concurrent validity, and content validity. The proposed item measures were reviewed by supply chain and logistics academics and managers from leading courier companies in Australia. 29 uncertainty and risk variables were finalised in the questionnaire (Table 1).

Table 1. The Proposed Supply Chain Uncertainty and Risk Item Measures

\begin{tabular}{|c|c|c|}
\hline & Uncertainty and Risk Variables & Sources \\
\hline $\begin{array}{l}\text { Logistics } \\
\text { Uncertainties and } \\
\text { Risks } \\
\text { (LUR) }\end{array}$ & $\begin{array}{l}1 \text { Inadequate operational strength } \\
2 \text { Storage issues } \\
3 \text { Delays in pickup / delivery } \\
4 \text { Poor design of company's transportation network } \\
5 \text { Improper packaging and marking details } \\
6 \text { Damages due to accident/improper stacking/sorting } \\
7 \text { Breakdown of equipment, trucks and/or delivery vans } \\
8 \text { Processes errors } \\
9 \text { Lost / missing freight }\end{array}$ & $\begin{array}{l}\text { Murugesan et al., 2013; } \\
\text { Rodrigues et al., 2008; } \\
\text { Simangunsong et al., 2012; } \\
\text { Hauser, } 2003\end{array}$ \\
\hline $\begin{array}{l}\text { Information } \\
\text { Uncertainties and } \\
\text { Risks } \\
\text { (IUR) }\end{array}$ & $\begin{array}{l}1 \text { Delay or unavailability of the delivery information } \\
2 \text { Incorrect information } \\
3 \text { Poor communication between company and drivers } \\
4 \text { Breakdown of external/internal IT system, mobile phone and/or scanners } \\
5 \text { Poor security of information system } \\
6 \text { Poor information sharing within company } \\
7 \text { Information confusion }\end{array}$ & $\begin{array}{l}\text { Murugesan et al., 2013; } \\
\text { Simangunsong et al., 2012; } \\
\text { Guo et al., 2006; Cucchiella and } \\
\text { Gastaldi, 2006; Blackhurst et } \\
\text { al., 2008; Sanchez-Rodrigues et } \\
\text { al., } 2010\end{array}$ \\
\hline $\begin{array}{l}\text { Customer-related } \\
\text { Uncertainties and } \\
\text { Risks } \\
\text { (CUR) }\end{array}$ & $\begin{array}{l}1 \text { Delays due to customer's mistakes } \\
2 \text { Customers refusing the freight charge } \\
3 \text { Customers changing the preference } \\
4 \text { Inaccurate forecast of customers' freight volume } \\
5 \text { Poor communication between company and customer } \\
6 \text { Damages due to customers' faults } \\
7 \text { Complexity of process } \\
8 \text { Higher customer expectation }\end{array}$ & $\begin{array}{l}\text { Murugesan et al., 2013; Manuj } \\
\text { and Mentzer, 2008; Sodhi and } \\
\text { Lee, 2007; Chopra and Sodhi, } \\
\text { 2004; Sodhi and Tang, } 2012\end{array}$ \\
\hline $\begin{array}{l}\text { Environment } \\
\text { Uncertainties and } \\
\text { Risks } \\
\text { (EUR) }\end{array}$ & $\begin{array}{l}1 \text { Labor / driver shortage } \\
2 \text { Road congestion/closures } \\
3 \text { Weather / Natural disasters/ industrial action } \\
4 \text { Unstable fuel prices } \\
5 \text { Uncertainty due to government laws / regulation }\end{array}$ & $\begin{array}{l}\text { Murugesan et al., 2013; } \\
\text { Blackhurst et al., 2008; } \\
\text { McKinnon and Ge, 2004; } \\
\text { Sanchez-Rodrigues et al., 2010; } \\
\text { Simangunsong et al., 2012 }\end{array}$ \\
\hline
\end{tabular}

A scale is used to rate the importance of each uncertainty / risk variable with reference to severity of impact in the Australian courier company based on the 7 point scale rating, 1- no problem, 2 - minimal problem, 3 - mild problem, 4 moderate problem, 5 - moderately severe problem, 6 severe problem, 7 - very severe problem. If an uncertainty or risk variable has a very high impact in the Australian courier company that means the rating should be maximum (i.e. 7), if it has no impact then the rating should be least (i.e. 1), and if it is in between these two ranges, the rating should be between 2 to 6 based on their severity

Then, the online questionnaires were circulated among the practitioners who have experience and knowledge in the Australian courier industry. We distributed 1000 questionnaires in the Australian courier industry. Total 220 responses were received. The response rate is 22 per cent. The IBM SPSS version 21 and SmartPLS version 2.0.M3 statistical software package are chosen in this study.

\subsection{Reliability and Validity}

The measurement was tested for its reliability and validity. Reliability is an assessment of the degree of consistency between multiple measurements of a variable (Hair, 2010). This study applies reliability coefficient with Cronbach's alpha to test the reliability of the scale. The reliability is demonstrated by Cronbach's alpha greater than 0.7 in SPSS (Hair, 2010). Reliability is demonstrated by Composite Reliability (CR) greater than 0.700 in SmartPLS. Cronbach's alpha indicates the supply chain uncertainty and risk measurement has a high level of reliability.

Validity is another important dimension to indicate the degree of accuracy of measurements. Face or content 
validity is tested in the pilot study. This section examines both convergent validity and discriminant validity. Convergent validity assesses the degree to which two measures of the same concept are correlated (Hair, 2010). High correlations are required to ensure the convergent validity, great than 0.7 is considered as a satisfaction level. In contrast, discriminant validity is the degree to which two conceptually similar concepts are distinct (Hair, 2010). Convergent validity is demonstrated by loadings greater than 0.700 , average variance extracted (AVE) greater than 0.500, and Communalities greater than 0.500. Discriminant validity is demonstrated by the square root of the AVE being greater than any of the inter-construct correlations (Hair et al., 2012).

SPSS offers five rotation methods: varimax, direct oblimin, quartimax, equamax, and promax, in that order. Three of those are orthogonal (varimax, quartimax, \& equimax), and two are oblique (direct oblimin \& promax).
To choose the two rotation methods that is based on the whether the factors are believed to be correlated (oblique) or uncorrelated (orthogonal) (Vogt, 1993). Gorsuch (1983) recommends varimax method should be used for orthogonal or promax method should be used for oblique. Principal Axis Factoring (PAF) with promax method is used to explore the factors, a minimum eigenvalue of 1 were chosen as conditions for factor extraction. Items were allocated to a factor if their primary loading was greater than 0.5 , if they did not cross load onto more than one factor and if their communality is greater than 0.4. During the factor analysis, three underlying factors of supply chain uncertainty and risk are extracted. They are company-side uncertainty and risk (OUR), customer-side uncertainty and risk (CUR), and environment uncertainty and risk (EUR). Overall, the reliability and validity analysis of supply chain uncertainty and risk measurement is summarised in Table 2.

Table 2. The Validity and Reliability Analysis of a Measurement Model of Supply Chain Uncertainty and Risk in the Australian Courier Industry

\begin{tabular}{|c|c|c|c|c|c|c|c|c|c|}
\hline Construct & Factors & Items & & $\begin{array}{l}\text { Number of } \\
\text { items }\end{array}$ & $\begin{array}{l}\text { Average } \\
\text { mean value }\end{array}$ & $\begin{array}{l}\text { Cronbach's } \\
\text { alpha }\end{array}$ & AVE & $C R$ & Communality \\
\hline \multirow{3}{*}{ SCUR } & $\begin{array}{l}\text { Company-side } \\
\text { uncertainty and } \\
\text { risk } \\
\text { (OUR) }\end{array}$ & $\begin{array}{l}\text { LUR_1 } \\
\text { LUR_3 } \\
\text { IUR_6 }\end{array}$ & $\begin{array}{l}\text { LUR_2 } \\
\text { IUR_3 }\end{array}$ & 5 & 2.324 & 0.90 & 0.72 & 0.93 & 0.72 \\
\hline & $\begin{array}{l}\text { Customer-side } \\
\text { uncertainty and } \\
\text { risk } \\
\text { (CUR) }\end{array}$ & $\begin{array}{l}\text { CUR_1 } \\
\text { CUR_4 }\end{array}$ & CUR_3 & 3 & 2.487 & 0.89 & 0.82 & 0.94 & 0.82 \\
\hline & $\begin{array}{l}\text { Environment } \\
\text { uncertainty and } \\
\text { risk (EUR) }\end{array}$ & $\begin{array}{l}\text { EUR_1 } \\
\text { EUR_3 } \\
\text { EUR_5 }\end{array}$ & $\begin{array}{l}\text { EUR_2 } \\
\text { EUR_4 }\end{array}$ & 5 & 2.472 & 0.86 & 0.78 & 0.86 & 0.78 \\
\hline
\end{tabular}

According to the empirical data, a measurement model for supply chain uncertainty and risk is developed in the Australian courier industry. The measurement model of supply chain uncertainty and risk (SCUR) consisting of company-side uncertainty and risk, customer-side uncertainty and risk, and environment uncertainty and risk is shown in Figure 1. For the reflective indicators, reliability of an individual item is assessed by its loading on the intended construct. Hair et al. (2012) urge a rule of thumb to consider only factor loadings of at least 0.7. Figure 1 also shows the results of the factor loading. The results show the high reliability of the measurement model.

\section{DISCUSSION}

For managers, they have to manage all kinds of supply chain uncertainties and risks in a real-world environment. Therefore, a reliable and appropriate measurement does not only enable academics to perform a further research on supply chain uncertainty and risk, but also allow managers to have a holistic view of supply chain uncertainty and risk, so that the managers can make a decision effectively and efficiently. Furthermore, both supply chain risk and uncertainty management strategies request a reliable and appropriate uncertainty and risk measurement for assessment of supply chain uncertainty and risk in industries (Aven, 2011).

In the Australian courier industry, we found the three main factors of supply chain uncertainty and risk consisting of company-side uncertainty and risk, customer-side uncertainty and risk, and environment uncertainty and risk. They were identified through the factor analysis. Companyside uncertainty and risk includes logistics uncertainty and risk items and information uncertainty and risk items. It represents the supply chain uncertainties and risks, which are occurred inside the Australian courier companies. The previous logistics uncertainty and risk, and information uncertainty and risk are reconstructed as one single factor company-side uncertainty and risk. In order to have a logical consistency in the supply chain uncertainty and risk measurement, customer-related uncertainty and risk was renamed to customer-side uncertainty and risk. It comprises previous customer-related uncertainty and risk items. And it is defined as supply chain uncertainty and risk, which are most likely occurred at customers' side. Environment uncertainty and risk remains the same. The supply chain environment uncertainty and risk can occur due to the linkage between the supply chain network and its external environment. 


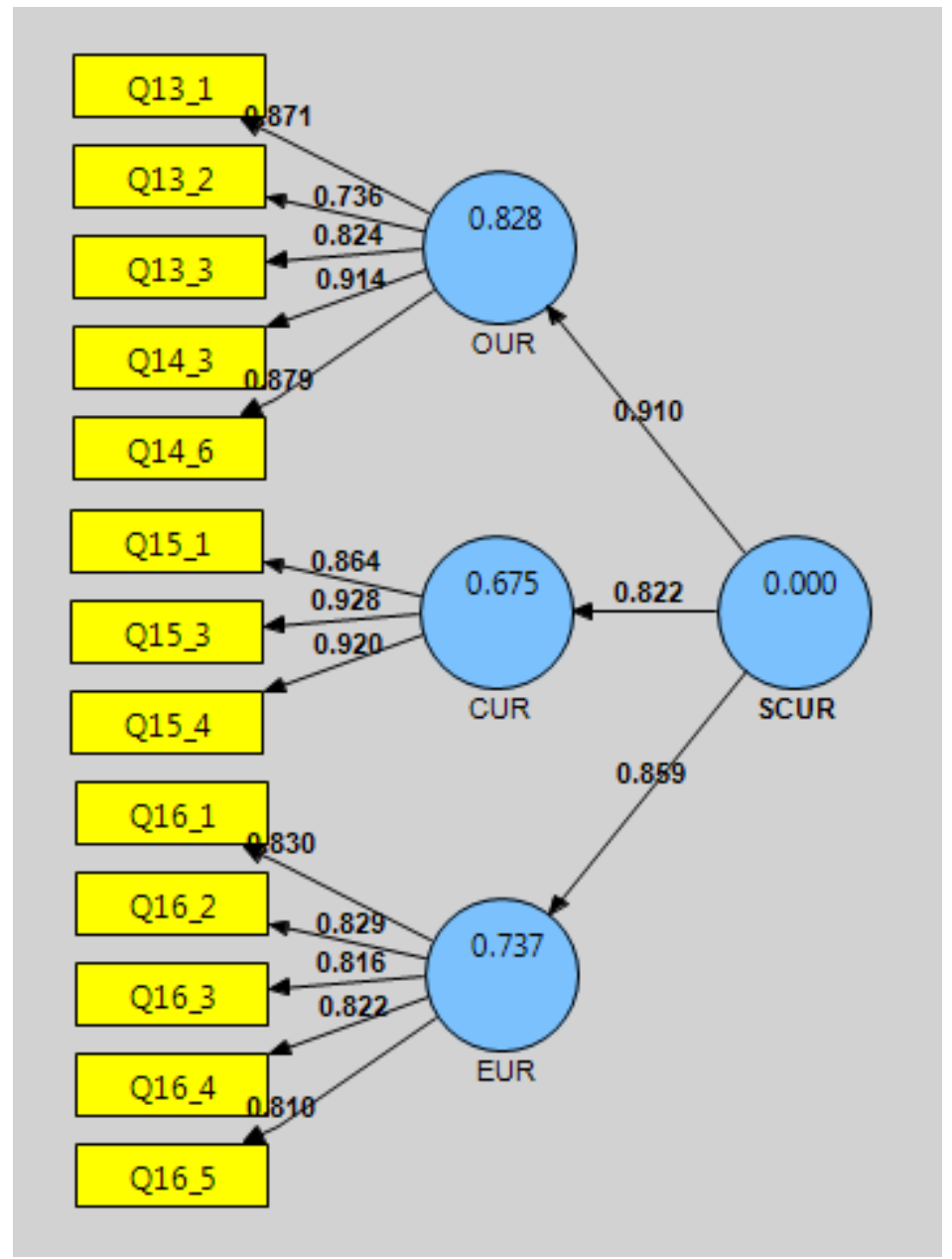

Figure 1. A Measurement Model for Supply Chain Uncertainty and Risk in the Australian Courier Industry

Environment risk comprises any uncertainties arising from the supply chain environment interaction (Jüttner et al., 2003). The three underlying factors of supply chain uncertainty and risk are found for first time in the Australian courier industry. The results show high levels of reliability and validity of the measurement model.

Customer-side uncertainty and risk has the highest average mean value 2.487 . Then, environment uncertainties and risks with the second highest average mean value 2.472 . Company-side uncertainty and risk has the lowest average mean value 2.324. Obviously, in the Australian courier industry, the greatest impact of supply chain uncertainty and risk was from customer-side uncertainty and risk. This implies that the Australian courier companies should pay attention to the external uncertainty and risk including customer-side and environment uncertainty and risk.

We take a closer look at the underlying factors, the top five greatest impacts of logistics uncertainties and risks in the Australian courier industry was delays, customers' mistakes, higher customer expectation, unavailability of the delivery information and lost / missing freight. The results in line with the previous study Sanchez-Rodrigues et al. (2009) and Manuj and Mentzer (2008). Customer as a major factor has been widely discussed in the logistics and supply chain. Traditionally, customer is considered as two different parties - supply and demand side in the supply chain (Murugesan et al., 2013). In this study, we focus on the courier industry. Both sender and receiver play an important role in a courier company. The results reveal that the customer is an important factor in the supply chain uncertainty and risk in the Australian courier industry.

\section{CONCLUSION}

Over the past decade, some authors started paying attention to supply chain risk and uncertainty in transport and logistics operations (Sanchez-Rodrigues et al., 2010; Rodrigues et al., 2008). Supply chain risk and uncertainty in logistics and transport can broadly be categorised as the potential disturbances to the flow of goods, information and money (Ellegaard, 2008). For example, Sanchez-Rodrigues et al. (2010) state transport-related uncertainty, and the main drivers impacting the sustainability and transport operations are delays, variable demand / poor information, delivery constraints and insufficient supply chain integration. Vorst and Beulens (2002) identify sources of uncertainty for supply chain redesign strategies. Rodrigues et al. (2008) develop a logistics-oriented uncertainty model - the logistics uncertainty pyramid model, which includes five sources of uncertainty related to suppliers, customer, carrier, control system and external environment. Sanchez-Rodrigues et al. (2010) evaluate the causes of uncertainty in logistics operations. Most studies focus on the identification of supply chain uncertainty and risk. Literally, we need a reliable and appropriate measurement for assessing the supply chain uncertainties and risks in logistics and transport industries. 
This paper provides a contribution to the supply chain uncertainty and risk literature. The results reveal the three underlying factors of the supply chain uncertainties and risks in the Australian courier industry. The measurement may be used to assess supply chain uncertainty and risk based on their impacts in the different context. The study focuses on the Australian courier industry. Thus, any generalisation to other countries, industries or sectors must be made with caution. Supply chain uncertainty and risk can be categorised in terms of different perspectives (Christopher and Peck, 2004).

As a future study, the measurement model could be used in a framework to test the relationships between supply chain uncertainty and risk, and other constructs. This would improve the effectiveness and efficiency of supply chain uncertainty and risk management in a particular context, and help the practitioners to focus their attention and develop uncertainty and risk management strategies based on the relative importance of supply chain uncertainty and risk variables in their companies.

\section{REFERENCES}

Andreas, W and Carl Marcus, W (2012), Dealing with Supply Chain Risks Linking Risk Management Practices and Strategies to Performance, International Journal of Physical Distribution \& Logistics Management 42(10), pp. 887-905.

Aven, T (2011), Quantitative Risk Assessment : the Scientific Platform, Cambridge University Press, New York.

Blackhurst, JV, Scheibe, KP and Johnson, DJ (2008), Supplier Risk Assessment and Monitoring for the Automotive Industry, International Journal of Physical Distribution \& Logistics Management 38(2), pp. 143165.

Chopra, S and Sodhi, MS (2004), Managing Risk to Avoid Supply Chain Break Down, MIT Sloan Management Review 46(1), pp. 53-61.

Christopher, M (1998), Logistics and Supply Chain Management : Strategies for Reducing Cost and Improving Service, 2nd ed. edn, London : Finacial Times Management, London.

Christopher, M and Lee, H (2004), Mitigating Supply Chain Risk Through Improved Confidence, International Journal of Physical Distribution \& Logistics Management 34(5), pp. 388-396.

Christopher, M and Peck, H (2004), Building the Resilient Supply Chain, The International Journal of Logistics Management 15(2), pp. 1-14.

Cucchiella, F and Gastaldi, M (2006), Risk Management in Supply Chain: A Real Option Approach, Journal of Manufacturing Technology Management 17(6), pp. $700-720$.

Davis, T (1993), Effective Supply Chain Management, Sloan Management Review 34(4), pp. 35-46.

Ellegaard, C (2008), Supply Risk Management in a Small Company Perspective Supply Chain Management: An International Journal 13(6), pp. 425-434.

Gorsuch, RL (1983), Factor analysis, 2 edn, Lawrence Erlbaum Associates, Hillsdale, NJ.
Guo, Z, Fang, F and Whinston, AB (2006), Supply Chain Information Sharing in a Macro Prediction Market, Decision Support Systems 42(3), pp. 1944-1958.

Hair, JF (2010). Multivariate Data Analysis, 7th ed. edn, Prentice Hall, Upper Saddle River, NJ.

Hair, JF, Sarstedt, M, Pieper, TM and Ringle, CM (2012), The Use of Partial Least Squares Structural Equation Modeling in Strategic Management Research: A Review of Past Practices and Recommendations for Future Applications, Long Range Planning 45(5-6), pp. 320-340.

Hauser, LM (2003), Risk-adjusted Supply Chain Management, Supply Chain Management Review, 7(6), pp. 64-71.

Hult, GTM, Craighead, CW and Ketchen, JDJ (2010), Risk Uncertainty and Supply Chain Decisions: A Real Options Perspective, Decision Sciences, 41(3), pp. 435-458.

Jüttner, U, Peck, H and Christopher, M (2003), Supply Chain Risk Management: Outlining an Agenda for Future Research, International Journal of Logistics Research and Applications 6(4), pp. 197-210.

Knight, FH (1921), Risk, Uncertainty and Profit, Houghton Mifflin Company, Boston, New York.

Lam, J (2003). Enterprise Risk Management : from Incentives to Controls, Wiley, Hoboken, N.J.

Lee, HL (2002). Aligning Supply Chain Strategies with Product Uncertainties, California Management Review 44(3), pp. 105-119.

Manuj, I and Mentzer, JT (2008), Global Supply Chain Risk Management, Journal of Business Logistics 29(1), pp. 133-155.

March, J and Shapira, Z (1987), Managerial Perspectives on Risk and Risk Taking, 33(11), pp. 1404-1418.

Mason-Jones, R and Towill, DR (1998). Shrinking the Supply Chain Uncertainty Circle, IOM Control 24(7), pp. 17-22.

McKinnon, AC and Ge, Y (2004), Use of a Synchronised Vehicle Audit to Determine Opportunities for Improving Transport Efficiency in a Supply Chain, International Journal of Logistics Research and Applications 7(3), pp. 219-238.

McManus, H and Hastings, D (2006), A framework for Understanding Uncertainty and its Mitigation and Exploitation in Complex Systems, IEEE Engineering Management Review 34(3), pp. 81-81.

Miller, KD (1992), A Framework for Integrated Risk Management in International Business, Journal of International Business Studies 23(2), p. 311.

Murugesan, P, Natarajan, T and Lakshminarayanan, M (2013). Assessment of Supply Chain Risk: Scale Development and Validation, Benchmarking: An International Journal, 20(1), pp. 79-105.

Patil, DP, Shrotri, AP and Dandekar, AR (2012), Management of Uncertainty In Supply Chain, International Journal of Emerging Technology and Advanced Engineering 2(5), pp. 303-308.

Peck, H (2006). Reconciling Supply Chain Vulnerability, Risk and Supply Chain Management, International Journal of Logistics Research and Applications 9(2), pp. 127-142.

Prater, E (2005), A Framework for Understanding the Interaction of Uncertainty and Information Systems on 
Supply Chains, International Journal of Physical Distribution \& Logistics Management 35(7), pp. 524539.

Prater, E, Biehl, M and Smith, MA (2001), International Supply Chain Agility - Tradeoffs between Flexibility and Uncertainty, International Journal of Operations \& Production Management 21(5/6), pp. 823-839.

Ritchie, B and Brindley, C (2007), Supply Chain Risk Management and Performance: A Guiding Framework for Future Development, vol. 27, Emerald Group Publishing Limited, pp. 303-322.

Ritholtz, B (2012). Defining Risk Versus Uncertainty in The BIG Picture, vol. 2013.

Rodrigues, VS, Potter, A and Naim, MM (2010). The Impact of Logistics Uncertainty on Sustainable Transport Operations, International Journal of Physical Distribution \& Logistics Management 40(1/2), pp. 61-83.

Rodrigues, VS, Stantchev, D, Potter, A, Naim, M and Whiteing, A (2008). Establishing a Transport Operation Focused Uncertainty Model for the Supply Chain, International Journal of Physical Distribution \& Logistics Management 38(5-6), pp. 388-411.

Sanchez-Rodrigues, V, Potter, A and Naim, MM (2009), The Impact of Logistics Uncertainty on Sustainable Transport Operations, International Journal of Physical Distribution and Logistics Management 40(12), pp. 61-83.

Sanchez-Rodrigues, V, Potter, A and Naim, MM (2010). Evaluating the Causes of Uncertainty in Logistics Operations, International Journal of Logistics Management 21(1), pp. 45-64.
Sanchez-Rodrigues, V, Stantchev, D, Potter, A, Naim, M and Whiteing, A (2008), Establishing a Transport Operation Focused Uncertainty Model for the Supply Chain, International Journal of Physical Distribution \& Logistics Management, 38(5) pp. 388-411.

Simangunsong, E, Hendry, LC and Stevenson, M (2012), Supply-Chain Uncertainty: A Review and Theoretical Foundation for Future Research, International Journal of Production Research 50(16), pp. 4493-4523.

Sodhi, MS and Lee, S (2007). An Analysis of Sources of Risk in the Consumer Electronics Industry, Journal of the Operational Research Society 58(11), pp. 14301439.

Sodhi, MS and Tang, CS (2012). Managing supply chain risk, Springer US, Boston, MA.

Vogt, WP (1993), Dictionary of statistics and methodology: A nontechnical guide for the social sciences Sage, Newbury Park, CA.

Vorst, JGAJvd and Beulens, AJM (2002). Identifying Sources of Uncertainty to Generate Supply Chain Redesign Strategies, International Journal of Physical Distribution \& Logistics Management 32(6), pp. 409430.

Wagner, SM and Bode, C (2008), An Empirical Examination of Supply Chain Performance Along Several Dimensions of Risk, Journal of Business Logistics 29(1), pp. 307-325.

Waters, D (2011). Supply Chain Risk Management Vulnerability and Resilience in Logistics, 2nd ed. edn, Kogan Page, London.

Michael Wang. Michael Wang is a Casual Academic in the School of Business IT and Logistics, RMIT University, Melbourne, Australia. He has a Bachelor degree of Commerce at University of Auckland, Auckland, New Zealand, a Master degree of logistics and supply chain management from Massey University, Auckland, New Zealand. He is currently doing a $\mathrm{PhD}$ research at RMIT University. His main research areas are supply chain optimisation, reverse logistics, supply chain uncertainty and risk management, urban freight transport and logistics.

Ferry Jie. Ferry Jie is a Senior Lecturer in Supply Chain and Logistics Management and Deputy and Program Director Master of Supply Chain and Logistics Management in the School of Business IT and Logistics, RMIT University, Melbourne, Australia. His main research areas are supply chain management, logistics, operations/production management, quantitative management/operations research/management science, decision making, quality management, lean six sigma, strategic management, project management.

Ahmad Abareshi. Ahmad Abareshi is a Senior Lecturer in Supply Chain and Logistics Management and Program Director OUA Logistics \& SCM in the School of Business IT and Logistics, RMIT University, Melbourne, Australia. He has a range of research interests including the IT/IS capabilities, Green Logistics, Supply chain management, Operations management, Artificial Neural Networks, Quality Management. 